\title{
ETHYLENE EMISSION OF APPLES TREATED WITH 1-METHYLCYCLOPROPENE DURING STORAGE
}

\author{
Oleksandr MELNYK*, Olga DROZD, Natalia BOICHEVA, Yuliia ZHMUDENKO, \\ Igor MELNYK, Liudmyla KHUDIK, Leonid REMENIUK, Liubomyr VYKHVATNIUK \\ National University of Horticulture \\ 2 Instytutska Str., Uman, Ukraine, 20-305
}

Received: March 28. 2014 Accepted: June 13. 2014

\begin{abstract}
The effect of post-harvest application of 1-methylcyclopropene (1-MCP) on ethylene emission in early-winter apple (cv. 'Calville'), winter ('Gloster', 'Golden Delicious' and 'Jonagold'), and late-winter cultivars ('Granny Smith', 'Idared' and 'Reinette Simirenko') was investigated. The fruits were picked at a commercial harvest time and half of them were treated with 1 -MCP ('SmartFresh ${ }^{\mathrm{TM}}$ ' $0.068 \mathrm{~g} \cdot \mathrm{m}^{-3}$ ) for $24 \mathrm{~h}$ at $5{ }^{\circ} \mathrm{C}$. Then both groups of apples were placed in a common storage at the temperature of $2{ }^{\circ} \mathrm{C}$. The intensity of fruit ethylene emission (rate of ethylene production) was measured and 1-MCP inhibition index was calculated. During storage, activity of ethylene emission by control apples of 'Calville' and 'Golden Delicious' showed typical climacteric pattern, while the intensity of ethylene emission of apples of other cultivars only increased gradually. The change of ethylene activity of early-winter apple cv. 'Calville' and winter cv. 'Jonagold', both treated with 1-MCP after harvest, had exponential character, especially actively increasing after 3 months of storage. At the same time ethylene emission of 1-MCP treated fruits of other cultivars changed steadily to a low level and was effectively suppressed during the whole 6-month period of storage in normal atmosphere. The value of inhibition index of fruits treated by 1-MCP confirmed the consistent restoration of the ability to ethylene synthesis and thus to post-harvest ripening of some apples cultivars.
\end{abstract}

Key words: apples, 1-MCP, storage condition

\section{INTRODUCTION}

Ethylene, a ripening hormone of fruits, is physiologically active at a concentration $0.1-1.0$ $\mu \mathrm{l} \cdot \mathrm{dm}^{-3}$. It stimulates ripening in so-called climacteric fruits and plays an important role in metabolism (Bleecker \& Kende 2000). The intensification of ethylene synthesis by fruits is associated with better taste and flavour of apples, however their storage ability worsens. A physiological base of storage technology is control over fruit sensitivity to ethylene action, which is well ensured by postharvest treatment with 1-methylcyclopropene (1MCP) (Blankenship \& Dole 2003).
Post-harvest treatment of different horticultural products using ethylene inhibitor, 1-MCP, allows controlling ethylene responses over extended period and increases the efficiency of fruit storage (Sisler \& Serek 1997). 1-MCP has a great potential for quality maintenance of late season apple cultivars (i.e. 'Granny Smith') during storage by completely preventing superficial scald, which is the major problem for this cultivar (Çelikel et al. 2010). The efficacy of 1-MCP is affected by cultivar and storage conditions, and that successful commercial utilisation of the chemical will require understanding of these relationships (Watkins et al. 2000; Lu et al. 2013). 
Apple cultivars respond to 1-MCP treatment in different ways. Internal ethylene levels of 1-MCP treated fruits were an accurate indicator of treatment efficacy, storage potential and the physiological ripening responses of 'Golden Delicious' and 'Granny Smith' apples following storage and shelf life (Crouch 2010).

In the conditions of Ukraine, it has been found out that maximal ethylene emission of apple winter cultivar 'Golden Delicious' after harvesting and being kept at room temperature was higher than that of 'Jonagold', 'Idared' and 'Reinette Simirenko' - by 2.7, 13 and 7.6 times, respectively. Pre-climacteric increase of ethylene emission after 3-month refrigeration storage was possible for untreated fruits of winter cultivars 'Golden Delicious' and 'Jonagold', whereas ethylene emission intensity of untreated apples of late winter cultivars 'Idared' and 'Renette Simirenko' increased during 7-month refrigeration storage (Melnyk \& Drozd 2012).

The aim of this research was to determine the effect of post-harvest 1-MCP treatment of apples on the intensity of ethylene emission (rate of ethylene production) at various storage periods.

\section{MATERIALS AND METHODS}

Apples 'Idared', 'Golden Delicious', 'Granny Smith', 'Jonagold' and 'Renette Simirenko' were picked at a commercial harvest time in 2010 ('Calville' and 'Gloster' were picked in 2012). These apple cultivars represent early, mid and late season of ripening ranging from fast to slow. Apples were cooled to the temperature of $5{ }^{\circ} \mathrm{C}$ and treated with 1-MCP $\left(0.068 \mathrm{~g} \cdot \mathrm{m}^{-3}\right.$, 'SmartFresh ${ }^{\mathrm{TM}}$ ') in an airtight container for $24 \mathrm{~h}$, then were stored for 6 months at the temperature of $2{ }^{\circ} \mathrm{C}$ and humidity 90-95\% (non-treated fruits - control).

The intensity of fruit ethylene emission was periodically measured with gas analyser ICA-56 ("International Controlled Atmosphere Ltd.") after exposure of fruits, pre-heated to the temperature of $18-20{ }^{\circ} \mathrm{C}$. Measurements were made on separate batches of fruits. A sample of three or four fruits of a weight approximately $0.5 \mathrm{~kg}$ was placed in a 4 litre airtight jar and maintained for $0.5-1 \mathrm{~h}$ at $20{ }^{\circ} \mathrm{C}$. Data are means of two replicates.
1-MCP inhibition index (II) was calculated according to formula:

$\mathrm{II}=1-\left(\mathrm{EE}_{\mathrm{t}} \times \mathrm{EE}_{\mathrm{nt}}^{-1}\right)$, where:

$E_{t}$ - ethylene emission of treated fruits,

$\mathrm{EE}_{\mathrm{nt}}$ - ethylene emission of non-treated fruits. The results were statistically evaluated using Statistica programme. Error bars represent SD. When bars are absent, the value for SD was within the dimensions of the symbol.

\section{RESULTS AND DISCUSSION}

During storage ethylene emission by untreated fruits 'Calville' and 'Golden Delicious' showed typical climacteric pattern with maximum rate on the $60^{\text {th }}$ and $150^{\text {th }}$ day of cold storage, respectively, while the ethylene production of apples of other cultivars only increased gradually. The highest ethylene emission by control fruits - about $60 \mu \mathrm{l} \cdot \mathrm{kg}^{-1} \cdot \mathrm{h}^{-1}$ during climacteric was recorded for cultivar 'Golden Delicious' (that for 'Calville' was 42.5), the lowest one was $4.4 \mu \mathrm{l} \cdot \mathrm{kg}^{-1} \cdot \mathrm{h}^{-1}$ for cultivar 'Idared' (Fig. 1).

Post-harvest 1-MCP treatment of apples significantly affected the ethylene synthesis in fruits. The change of ethylene activity of early-winter apple cultivar 'Calville', treated with 1-MCP after harvest, has exponential character, especially actively growing after 3 months of storage - up to the level of $18 \mu \mathrm{l} \cdot \mathrm{kg}^{-1} \cdot \mathrm{h}^{-1}$ at the end of 6-month storage. A similar dependence was found for winter cultivar 'Jonagold' (ethylene production rate increased after 4 months of storage) but here the highest emission value was three times lower than the highest one in 'Calville' $-6 \mu \mathrm{l} \cdot \mathrm{kg}^{-1} \cdot \mathrm{h}^{-1}$. At the same time a level of ethylene activity of 1-MCP treated fruits of other apple cultivars does not exceeded $2.5 \mu \mathrm{l} \cdot \mathrm{kg}^{-1} \cdot \mathrm{h}^{-1}$ (Fig. 2).

The value of inhibition index resulted from post-harvest 1-MCP treatment confirmed the consistent restoration of the ability to ethylene synthesis and thus to post-harvest ripening of apples cultivars 'Jonagold', 'Gloster', 'Idared' and especially 'Calville'. At the same time, ethylene synthesis of fruits of other apple cultivars was effectively suppressed during the whole 6-month period of refrigeration storage (Fig. 3). When ethylene synthesis was limited considerably, fruits treated 
with 1-MCP after harvesting failed to reach marketing maturity. The same was observed by Vanoli et al. (2010) in pears storage.

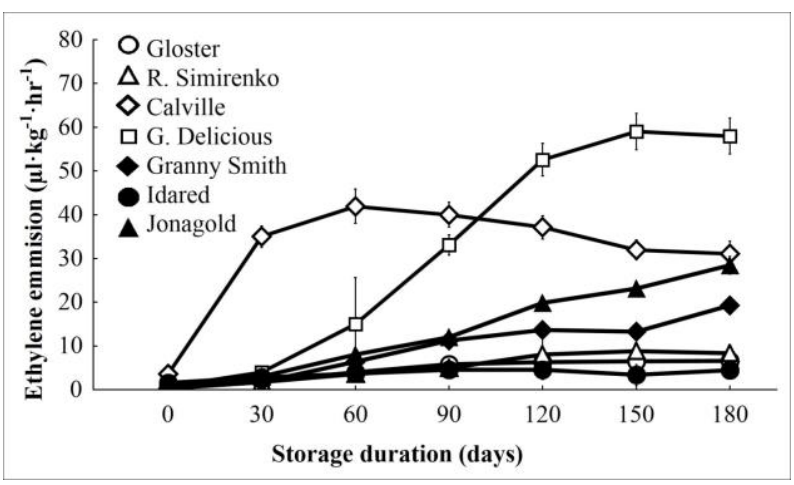

Fig. 1. Ethylene emission at $20{ }^{\circ} \mathrm{C}$ by control apples stored for 6 months at $2{ }^{\circ} \mathrm{C}$

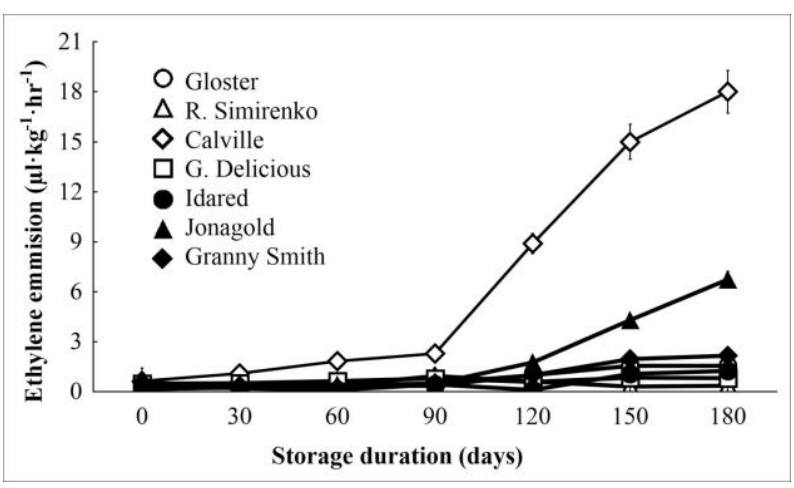

Fig. 2. Ethylene emission at $20{ }^{\circ} \mathrm{C}$ by apples treated with 1-MCP after harvesting and stored for 6 months at $2{ }^{\circ} \mathrm{C}$

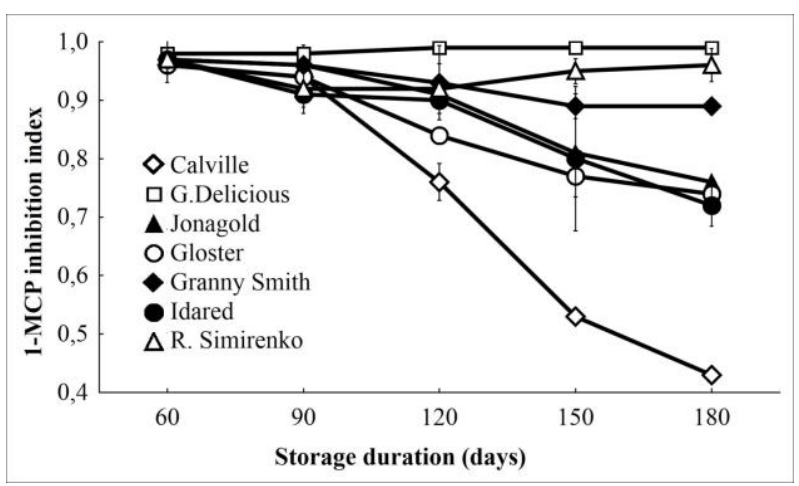

Fig. 3. The inhibition index of ethylene emission by apples treated with 1-MCP after harvesting and stored for 6 months at $2{ }^{\circ} \mathrm{C}$

\section{CONCLUSION}

Post-harvest treatment of apple fruits with ethylene inhibitor 1-MCP (coming from product 'SmartFresh ${ }^{\mathrm{TM}}$ ') reduces significantly ethylene emission of winter apple cultivars during refrigeration storage. However, it has a smaller effect on apple of early winter cultivar 'Calville'.

Further studies are needed to better clarify the relationship between cold storage, fruit maturity and factors influencing ethylene emission in apple fruits.

\section{Acknowledgement}

The authors express their gratitude to "AgroFresh" (Poland) for providing "SmartFresh ${ }^{\mathrm{TM}}$, preparation and ICA-56 device to carry out trials.

\section{REFERENCES}

Blankenship S.M., Dole J.M. 2003. 1-methylcyclopropene: a review. Postharvest Biol. Technol. 28: 1-25. http://dx.doi.org/10.1016/S0925-5214(02)00246-6

Bleecker A.B., Kende H. 2000. Ethylene: a gaseous signal molecule in plants. Annu. Rev. Cell Dev. Biol. 16: $1-18$.

Çelikel F.G., Özelkők S., Acican T., Aslım A.S. 2010. Effect of 1-MCP (1-methylcyclopropene) pretreatment on cold storage of 'Granny Smith' apples. Acta Hort. 877: 339-344.

Crouch I.J. 2010. Factors influencing the efficacy of commercially applied 1-methylcyclopropene (1-MCP). Acta Hort. 877: 297-303.

Lu X., Nock J. F., Ma Y., Liu X., Watkins C.B. 2013. Effects of repeated 1-methylcyclopropene (1-MCP) treatments on ripening and superficial scald of 'Cortland' and 'Delicious' apples. Postharvest Biol. Technol. 78: 48-54. http://dx.doi.org/10.1016/j.postharvbio.2012.12.007

Melnyk O., Drozd O. 2012. Ethylene activity and components of the chemical composition of apples with postharvest treatment of ethylene inhibitor. Scientific reports of NULES of Ukraine 5(34). http://nd.nubip.edu.ua/2012_5/titul.html [in Ukrainian with English abstract]

Sisler E.C., Serek M. 1997. Inhibitors of ethylene responses in plants at the receptor level: recent developments. Physiol. Plant. 100: 577-582. http://dx.doi.org/10.1111/j.1399-3054.1997.tb03063.x 
Vanoli M., Zerbini P.E., Grassi M., Rizzolo A. 2010. Ethylene production and quality in 1-methylcyclopropene treated 'Abbé Fétel' pears after storage in dynamically controlled atmosphere. Acta Hort. 876: 31-38.
Watkins C.B., Nock J.F., Whitaker B.D. 2000. Responses of early, mid and late season apple cultivars to postharvest application of 1-methylcyclopropene (1-MCP) under air and controlled atmosphere storage conditions. Postharvest Biol. Technol. 19: 17-32. http://dx.doi.org/10.1016/S0925-5214(00)00070-3 